Nigerian Joumal of Physiological Sciences 18 (1-2): 59-64@ Physiological Society of Nigeria 2003

\title{
EFFECT OF GARCINIA KOLA SEED ALKALOID EXTRACT ON LEVELS OF GONADAL HORMONES AND PITUTARY GONADOTROPHINS IN RAT SERUM
}

\author{
V. R. BRAIDE, C. A, AGUBE, G. E. ESSIEN and F. V. UDOH \\ Department of Pharmacology, College of Medical Sciences, University of Calabar, PMB 1115 , Calabar, Nigeria
}

Summary: The effects of three tolerated oral doses $(350 \mathrm{mg} / \mathrm{kg}, 1500 \mathrm{mg} / \mathrm{kg}, 2000 \mathrm{mg} / \mathrm{kg})$ of methanolic alkaloid extract of Garcinia kola seed (GKA) on serum levels of estradiol, progesterone, prolactin, FSH and LH were observed in female rats $(125-170 \mathrm{~g})$. The control animals received $2 \mathrm{ml}$ oral doses of methanolic saline $(0.9 \% \mathrm{NaCl})$ daily and the treatment period of dosing for all animals lasted 3,7 or 30 days, at the end of which they were exsanguinated to collect serum for hormonal assays. In another study, the effects of daily oral doses of GKA (350 mg/kg or $2000 \mathrm{mg} / \mathrm{kg}$ for days; $300 \mathrm{mg} / \mathrm{kg}, 1300 \mathrm{mg} / \mathrm{kg}$ or $2000 \mathrm{mg} / \mathrm{kg}$ for days; $1500 \mathrm{mg} / \mathrm{kg}$ for 14 days) on serum levels of testosterone, LH and FSH were observed in male rats $(150-175)$. The experiments showed that serum LH, FSH and prolactin levels were lower, while estradiol and progesterone levels were higher, than control values in females. There was marked reduction in serum testosterone and a concomitant elevation of serum FSH and LH in males. The findings suggest a possible antifertility consequence of treatment with GKA.

Key Woras: Garcinia kola seeds; alkaloids; gonadotrophins; sex hormones.

\section{Introduction}

Garcinia Kola Heckel (Guttiferae) is a large fruit tree that abounds in the rain forest belt of Southern Nigeria. The seed ("bitter kola") is used by traditional Nigerian herbal doctors to treat ailments such as diarthea, hepatitis, asthma, dysmenorthea or menstrual cramps (Dalziel, 1937). Preliminary investigations of the action of alkaloid and bioflavonoid fractions of the G. kola seed indicated marked, dose - dependent, reversible spasmolytic and antispasmogenic effects on uterine and gastrointestinal smooth muscle (Braide, 1989).

Chronic ingestion of $\mathrm{G}$. kola seed was observed to induce histopathological changes in liver parenchymal cells, renal tubular epithelium and duodenal villous epithelium (Braide, 1990; Braide and Gril, 1990). These changes were surmised as being attributable to the biflavonoids contained in $G$. kola seed. Other studies using methanolic extracts, or isolated alkaloid and bifavonoid fractions of the seed, showed that these phytochemical principles stimulated an increase in gastric acid secretion (Oluwole and Obatomi, 1991); exhibited antihepatotoxic biochemical effects (Iwu, 1985; Akitonwa and Essien, 1990;Braide, 1991 a, b; Adegoke et al., 1998; Adaramoye and Akinloye, 2000; Farombi, 2000; Farombi et al. 2000), hypoglycaemic anti-diabetic activity (wu et al.4 1990) and antipyretic, antinfiammatory effects (Braide, 1993), It has also been observed that ingestion of G. kola seed caused mild bronchodilatation in man (Orie and Ekon,
1993) thus justifying its use in therapy of asthmatic patients by traditional herbal medicine practitioners in Nigeria.

Plant extracts have been found to induce testicular atrophy with consequent deterioration of reproductive or sexual function, as has been documented in the case of gossypol (Udo and Patil, 1992). Also, an earlier study observed that animals fed with subterranean clover, rich in isoflavones, suffered serious breeding impairment (Cheng et al., 1995).

Since G. kola seed is an important ingredient in material medica of traditional herbal medical practice, it was considered relevant to investigate its effect on male and female reproductive systems of experimental animals, in order to have some inkling as to possible effects in humans. The objective was to determine if the alkaloid extract of G. kola seed (GKA) directly affected the gonads and other parts of the reproductive system in male and female rats, or if the effects were secondary to alterations in central gonadotrophin regulation.

\section{Materials and Methods}

Preparation of Plant Extracts.

Fresh seeds of Garcinia kola, purchased in season from the local markets in Calabar, were peeled to remove the testa, washed and air-dried for $8 \mathrm{~h}$, then subsequently dried in an electric oven (Astell Hearson, England) thermostatically 
controlled at $40^{\circ} \mathrm{C}$ for $12 \mathrm{~h}$. The dry seeds were ground to a tine powder with the aid of a mortar and pestle. Herbarium specimens were deposited in the ethnophamacology unit of the Department of Pharmacology of the University of Calabar.

Batches of the $G$, kola seed powder $(100 \mathrm{~g}$ wt) were separately wraped in a thimble and placed a Soxhlet extractor ( $M$ \& $O$ Scientific $C o$, England) fitted to a $1,000 \mathrm{ml}$ round-bottom flask containing $500 \mathrm{ml}$ of either petroleun ether (40$60^{\circ} \mathrm{C}$ ) or methanol as extracting solvents.

The seed powder was extracted first with petroleum ether for $12 \mathrm{~h}$ to remove fat and other organic constituents soluble only in ether. The ether extract in the flask was decanted and then replaced with $500 \mathrm{~m}$ methanol. The etherextracted powder residue was then resubjected to Soxhlet axtraction in methanol for $72 \mathrm{~h}$. The methanol extract was evaporated to dryness at $45^{\circ} \mathrm{C}$ in vacuo, using a rotary evaporator and the powder so obtained was subsequently processed by Soxhlet extraction in petroleum ether at $50^{\circ} \mathrm{C}$ for 8 , to furthe remove and discard unwanted substances soluble in petroleum ether. The power residue contaning substances not soluble, and therefore not extractuble, in petroleum ether contained biothavonod and alkaloids of the $\mathrm{G}$. kola seed (Brain and Turner, 1975) and was then partitioned in equal volumes of chloroform and water for $24 \mathrm{~h}$ in a separating funnel. The water soluble phase, which contains alkaloid constituents, was evaporated in vacuo, to powder form, in a rotary evaporator. The alkaloid powder was stored in a refrigerator at $4^{\circ} \mathrm{C}$ until used for experiments reported in this study.

\section{Animals.}

The aninals used in the study were young adult, virgin male $(150 \cdots 175 \mathrm{~g})$ and female $(125 \ldots$ $170 \mathrm{~g}$ ) albino Wistar rats of a stram obtained from the Natonal Veterinary Research Institute at Vom, near Jos, in Plateau State, Nigeria. The animals were alowed one week of acclimatization to conditions of the animal housing faclity (26 -. $28^{\circ} \mathrm{C} ; 60-80 \%$ relative humidity; 14 light: $10 \mathrm{~h}$ dark cycle;. The animals were housed individually in wire mesh cages and received food (Agrofeed Mils lkot Omin, Calahar, Nigeria with composition: protein, $18 \%$ : fats, $3.5 \%$; fibe, $3.8 \%$; calcum, $1 \%$; phosphons, $0.68 \%$; metabolizable ener $5 \mathrm{y}, 2905 \mathrm{kcal} / \mathrm{kg}$ ) and tap water ad libitum.

\section{Preparaiton of Extract for Administration.}

The powder extract of $\mathrm{G}$. kola seed (GKA) which contained only alkaloid constituents (water - sonble but chloroform - insoluble), was made inco a stock solution of $1 \mathrm{~g} / \mathrm{m}$ l concentration in $0.9 \% \mathrm{NaCl}$, prior to oral administration to the experimental animals.

Collection and Handling of Blood Serum:

The animals were anesthetised in a chloroform chamber at the end the treatment period, and blood was obtained through cardiac puncture. Blood samples from each animal were put in well-labelled nonheparinized sample tubes which were then allowed to stand for $3 \mathrm{~h}$ in iced water and later centrifuged at $7,000 \mathrm{~g}$ for 10 minutes. The serum was then collected and stored at $-15^{\circ} \mathrm{C}$ for two days before hormonal assay.

\section{Hormonal Assay}

Serum samples were assayed for the following hormones: follicle stimulating hormone (FSH); luteinizing hormone (LH): estrogen (estradiol); progesterone; prolactin; and testosterone. The method used involved the microwell enzyme-linked immunoassay (ELISA) using analytical grade reagents (Syntron Bioresearch inc., USA).

\section{Statistical Analysis}

All data for control and experimental animals were subjected to statistical evaluation, using the student's t-test for significant differences, between control and experimental groups, at values of $p<0.05$.

\section{Results}

Effect of $G$. kola seed diet on serum gonodotrophins and iestosterone in male rats.

Male rats fed for 6 weeks on diets containing various levels of $\mathrm{G}$. Kola seed powder (CKP) were studied at the end of the feeding period. The diets contained GKP at levels of $10 \%$ $\mathrm{w} / \mathrm{w}(18 \mathrm{~g} / \mathrm{kg} / \mathrm{day}), 30 \% \mathrm{w} / \mathrm{w}(54 \mathrm{~g} / \mathrm{kg} / \mathrm{day})$ and $60 \% \mathrm{w} / \mathrm{w}(108 \mathrm{~g} / \mathrm{kg} /$ day). The GKP diet caused an increase in serum concentrations of pituitary gonadotrophins (FSH and LH) and a concomitant decrease in serum levels of testosterone in a dose related manner (Table 1). The most significant changes were observed in rats fed on the $30 \% \mathrm{w} / \mathrm{w}$ and $60 \%$ w/w GKP diets.

Effects of oral doses of $G$. hola alkaloid extract (GKA) on serum gonadotrophins and testosterone in male rats.

Male rats receiving daily oral doses ( 1500 $\mathrm{mg} / \mathrm{kg} /$ day) of GKA for 14 days showed statistically significant increases in FSH and LH concentrations in serum and decreased serum testosterone levels (Table 2). 
Effect of oral doses of $G$. kola alkaloid extract (GKA) on serum levels of gonadotrophins, prolactin and ovarian hormones in female rots.

Female rats receiving daily various oral doses of GKA $(350,1500,2000 \mathrm{mg} / \mathrm{kg} /$ day $)$ for various periods of treatment $(3,7,30$ days) exhibited increased levels of serum FSH, LH and prolactin and concomitant decreased levels of serum estradiol and progesterone. These changes were statistically significant and dose - related. The data in respect of treatment lasting for 30 days are shown in Table. 3.

Table 1. Effects of G. kola seed powder (GKP) diet on follicle stimulating hormone (FSH), Iuteinizing hormone (LH) and testosterone levels in serum of male rats after 6 weeks jeeding.

\begin{tabular}{|c|c|c|c|}
\hline \multirow[t]{2}{*}{ Diet } & \multicolumn{3}{|c|}{ Serum concentration $(n g / m)$} \\
\hline & FSH & LH & Testosterone \\
\hline $\begin{array}{l}\text { Control, } \\
\text { O\% GKP (S) }\end{array}$ & $0.7 \pm 0.001$ & $4.2 \pm 0.01$ & $400 \pm 2$ \\
\hline $\begin{array}{l}10 \% \text { GKP, w/w or } \\
18 \mathrm{gkE} \text { day }(5)\end{array}$ & $1.5 \pm 0.01\left(^{*}\right)$ & $4.5 \pm 0.05$ & $0.11 \pm 0.01\left(^{*}\right)$ \\
\hline $\begin{array}{l}30 \% \text { GKP, w/w or } \\
54 \mathrm{~g} / \mathrm{kg} / \mathrm{day}(5)\end{array}$ & $4.0 \pm 0.1\left(^{*}\right)$ & $5.1 \pm 0.1\left(^{*}\right)$ & $\left.0.05 \pm 0.0011^{*}\right)$ \\
\hline $\begin{array}{l}60 \% \text { GKF, w/w } \\
0 \mathrm{r} 108 \mathrm{~g} \mathrm{~kg} / \mathrm{day}(5)\end{array}$ & $5.5 \pm 0.05\left(^{*}\right)$ & $5.1 \pm 0.1\left(^{*}\right)$ & $0.04 \pm 0.005\left(^{*}\right)$ \\
\hline
\end{tabular}

The values are means \pm SEM; and the number in parenthesis represents the number of animals in each treatment group. (*) significantly different from control values $(P<0.05$, Student's t- test).

Table: 2 Effect of oral GKA (1500 $\mathrm{mg} / \mathrm{kg} / \mathrm{day})$ on serum concentrations of follicle stimulating hormone (FSH), liteinizing hormone (LH) and testosterone in male rats, after treatmen for 14 doys.

\begin{tabular}{lll}
\hline Treatment & Hormones & $\begin{array}{l}\text { Conc. in Serum } \\
\text { (ng/mi) }\end{array}$ \\
\hline Control(5) & FSH & $0.80 \pm 0.01$ \\
GKA (5) & FSH & $2.33 \pm 0.012\left(^{*}\right)$ \\
Control $(5)$ & LH & $4.26 \pm 0.04$ \\
GKA (5) & LH & $4.92 \pm 0.10\left(^{*}\right)$ \\
Control (5) & Testosterone & $13.06 \pm 0.30$ \\
GKA (5) & Testosterone & $2.13 \pm 0.06\left(^{*}\right)$
\end{tabular}

Values are expressed as means 1 SEM. Number in parentheses represents number of animats per treatment group. (\%) Significantly different from controls ( $p<0.05$, studewt's $i-t e s t)$. 


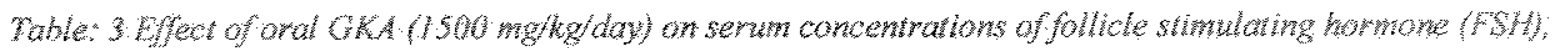

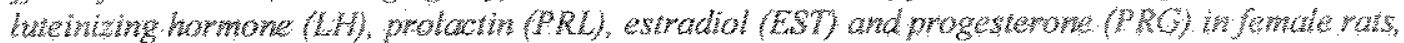
afere treatment for 30 dags

\begin{tabular}{|c|c|c|}
\hline Treatment & Hormones & Conc, in Serun \\
\hline Control $(5)$ & 75s & $14.72 \pm 0.52 \mathrm{mluml}$ \\
\hline SKA (5) & FSH & $\left.5.60+0.12 \mathrm{mbum} / \mathrm{m}^{*}\right)$ \\
\hline Contral $(5)$ & $\mathrm{LH}$ & $2.16 \pm 0.35 \mathrm{mu} / \mathrm{ml}$ \\
\hline OKA $(5)$ & Un & $1.50 \pm 0.12 \mathrm{mlu} / \mathrm{ml}(\mathrm{s})$ \\
\hline Control $(5)$ & PRL & $12.82 \pm 0.30 \mathrm{ng} / \mathrm{m}$ \\
\hline OKA $(5)$ & $\mathrm{MRL}$ & $10.10 \pm 0.38 \mathrm{mgm}(*)$ \\
\hline Control (s) & $\mathrm{PrO}$ & $10.10 .50 \mathrm{ng} / \mathrm{ml}$ \\
\hline GRA(5) & $\mathrm{PRO}$ & $14.0 \pm 0.65 \mathrm{mg} / \mathrm{ml}(*)$ \\
\hline Control $(5)$ & EST & $19.0 \pm 0.1 \mathrm{pg} / \mathrm{ml}$ \\
\hline OKA $(5)$ & EST & $38.0 \pm 0.2 \mathrm{pg} m(\mathrm{~m})$ \\
\hline
\end{tabular}

Vahes are expressed as means 4 SEM. Number in parentheses represents number of an imals per treatment group.

(*) Signithantly different from controls $(p<0.05$, Student's $t$-test).

\section{Discussion}

The study herein presented was instigated by an carlier finding that Garcinia lola seed diets, fed for durations lasting 6 weeks or longer, caused testicular atrophy, reduced relative testis weight, induced spermatogenesis aryest and resulted in degeneration of spermatozoa. These efects were replicated by oral doses of crude alkaloid extracts of the $G$. kola seed (Udoh, 1998). The present study is an attempt to explain the observations by Udoh (1998) on the basis of changes in the profles of serum gnedal and gonadotrophin hormones.

In this study it was observed that GKA caused a decrease in serum concentration of gonadorophins (FSH and LH) and prohactin, while comcidentally causing marked increase in serm level of ustradiol and progesterue in female rats. On the other hand, in male rats, GKA decreased the serum concentration of testosterone while increasing significantly the levels of FSH and $\mathrm{LH}$.

The above observation may be interpreted variously, depending on the sex of animas involved. In the male rat, bllowing long-term ingestion of $G$. hola seed, or oral administration of the alkaloid extract (GKA) thete is marked spermatogenesis arrest (Udoh, 1998). Possible explanations for such observation include a direct action of GKA on the testis, thereby causing inhibition of gondotrophic action in that organ. Other possib thies include preventing the release of pituitary gonadotrophins and/or clevation of blood levels of estosterone (via imhibition of hepatic metabolim) wereby induchng negative feedback effect on gonadotrophin release. It is not. phusible that prevention of gonadotrophim release is the likely mechanism in operation: because GKA actually was observed to enthance serun levels of ESH and LH in male rats. Furthermore, elevation of blood testosterone levels. is not a good explanation because GKA actually decreased serum levels of testosterone in male rats. The most plausible explanation of the observations on male rats in this study is the possibility of GKA inhibition of gonadotrophic action on the testis. This is in consonance with an wather study indicating that phenolic compounds are antispermatogenic (Udoh and Pakil, 1992). Any direct damage to the test is likely to impair gonadal response to FSH and $\mathrm{LH}_{3}$ such as diminished testosterone probuction due to lack of gonadal response to LH. Observations in this sevdy indicated that serum levels of testosterone were remarkably low, despite the mathed elevation of LH levels in blood.

The study of GKA treatment in semale rats gave somewhat differene results from those in male rats: decrease, instead of increase, in gonadotrophin levels and concomitunt escalation, instead of diminution, of gonadal (ovarian) homone (estradiol and progesteronelevels in serum. The serum level of mrolactin was also decreased. The most plausible explanation for these observations is that GKA may have a drect adverse effect on the female gonads, thus blocking their response to gonadotrophin (FSH and L.H.). follicle-stimulating homone (FSE) in female 
mammals stimulates maturation of the ovarian follicle and the release of oestrogen. Luteinizing hormone (LH) stimulates the release of progesterone from the ovarian corpus luteum. The diminished levels of gonadotrophins in serum should have resulted in decreased blood concentrations of the gonadal (ovarian) homones. This was not the case in this study. Rather, GKA caused elevation of serum levels of estradiol and progesterone in female rats. This could be due to a possibility of $\mathrm{GKA}$ causing impairment of hepatic catabolism of these ovarian hormones, and thus enhancing their accumulation and concentrations in serum. Earlier studies had indicated that Garcinia kola seed constituents could inhibit hepatic metabolism of drugs (Braide, $1991 \mathrm{a}, \mathrm{b}$; Farombi et $a l ., 2000$ ). The high levels of ovarian hormones presumably would cause, via negative feed-back mechanism on the hypothalamo-pituitary axis, decreased serum levels of FSH, LH and prolactin. This would be in line with observations that crude alkaloid extracts of the alligator pepper (Macroterms bellicosus) decreased prolactin levels in blood (Ebong et al., 1998). Furthermore an earlier study had demonstrated that the alkaloid drug bromocriptine reduced prolactin levels in blood via a central mechanism (Sandorama, 1986). It is unlikely that the GKA effects observed in this study have any direct central component; since Garcinia kola alkaloid has no effect on the CNS (Dalciel, 1956).

It is concluded that prolonged high-level exposure to Garcinia kola seed alkaloid induces profound changes in serum concentrations of gonadotrophins and gonadal hormones in rats; and that the direction of alteration (increase or decrease) depends significantly on the sex of animals under observation. These effects on the levels of gonodal hormones are most likely due to a primary peripheral action of GKA on the male and female reproductive systems, rather than being secondary to alterations by GKA in central gonadotrophin regulation.

\section{Acknowledgements}

The authors are grateful to $\mathrm{Mr}$. M. Akpanabiatu (Department of Biochemistry, University of Calabar) and Mr. Onyenokporoh (Chigozie Medical Diagnostic Laboratory, Aba) for their skillful technical assistance.

\section{References}

Adaramoye, O. A., and Akinloye, O. (2000). Possible protective effect of kolaviron or $\mathrm{rri}$ -induced erythrocyte damage in 63 Biological Science Repository 20 (4), 25y-104. Adegoke, G. O., Kumar, M. V., Sambiah, K., and Lokeshi, B. R. (1998). Inhibitory effect of
Garcinia kola on lipid peroxidation in rat liver homogenate. Indian Journal of Experimental Biology $36: 907-910$.

Akintonwa, A., and Essien, A. R., (1990) Protective effects of Garcinia kola seed extract against paracetamol-induced hepatotoxicity in rats. J. Ethnophrmacol. 29 (2), 207-211.

Braide, V. B. (1989). Antispasmodic extracts from seeds of Garcinia kola. Fitoterapia $L X, 123$. 129.

Braide, V. B. (1990). Pharmacological effects of chronic ingestion of Garcinia kola seeds in rats. Phytotherapy Res. 4: 39-41.

Braide, V. B. (1991 a). Antithepatotoxic biochemical effects of kolaviron, a bioflavonoid of Garcinia kola. Phytotherapy Res. 5, 35-37.

Braide, V. B. (1991 b), Inhibition of drug metabolism by flavonoid extract (kolaviron) of Garcinia kola seeds in rats. Phytotherapy Res. $5,38-40$.

Braide, V. B. (1993), Anti-inflammatory effect of kolaviron, a biflavonoid extract of Garcinia kola seeds in rats. Fitoterapia LXIV (50. 433436.

Braide, V. B., and Grill, V. (1990). Histological alterations by a diet containing seeds of Garcinia kola: effect on liver, kidney, and intestine in the rat. Gegenbaurs Morphol. Jahrb. 136 (1) 95-101.

Brain, K. R., and Tumer, T. D. (1975). The practical evaluation of phytopharmaceuticals. Bristol: Wright-Scientechinca, 10pp.

Cheng, F. W. Yoder, L., Storey, C. D., and Borroughs, W. (1955). Estrogenic activity of some naturally occurring isoflavones. Annols N. Y. Acad. Sci. 61, 652-659.

Dalziel, J. M. (1937). Flora of West Tropical Africa. (2nd edition) H. M. O. London vol. (1). P. 295. Dalziel, J. M. (1956) Useful Plants of Tropical Africa London: Grown Agents, 612 617.

Ebong, P. E. Eyong, E. U., and Lawal, A. S, (1998). Prolactin lowering effect of alligator pepper (Macroterms bellicosus). Nigerian J. Sci. 28

Farombi, O. E. (2000). Mechanisms for the hepatoprotective action of kolaviron: studies on hepatic enzymes, microsomal lipids and lipid peroxidation in carbontetrachloride treated rats. Pharmacol. Res. 42 (1), 75-80.

Farombi, O. E., Tahnteng, J. G., Agboola, A. O, Nwankwo, J. O., and Emerole, G. O. (2000). Chemoprevention of 2 - acetylaminofluorene - induced hepatotoxicity and lipid peroxidation in rats by k0laviron, a Garcinia kola seed extract. Food Chem. Toxicol, 38 (6), $535-541$. 
Iwu, M. (1985) Antihepatotoxic constituents of Garinia kola seeds. Experientia 41, 699-700.

Iwu, $M_{*}$ Igboko, $O$. A and Tempesta, M. S. (1990). Antidiabetic and aldose reductase activities of biflavanones of Garcinnia kola $J$. Pharm Pharmacol 42 (4), 290-292.

Oluwole, F. S, and Obatomi, A. B. (1990/91). The possible ulcerogenic effect of Garcinia conruana in rats West Afr. J. Pharmacol. Drug Res. 9/10,44-46.

Orie, N. N., and Ekon, E. U. A. (1993). The bronchodilator effect of Garcinia kola. East Afr. Med J. $70(30), 143-145$.
Sandorama Special Issue (1986). Prolactin related disorders in women. In: Neuroedocrinology, Sandox Ltd, Basel 14 - 16.

Udoh, P., and Patil, D. R. (1992). Effects of gossypol acetate on pituitary-adrenal axis in male albino rats. Contraception $45,263-271$.

Udoh, F, V. (1998). Effect of extracts of Garcinia kola seeds and Piper guineense leaves on morphology of reproductive organs of the male rat. M. Sc. Thesis, University of Calabar, Calabar, Nigeria, September 1998, 132pp.

Received: October 4, 2003

Accepted: November 14, 2003 